\title{
Predictors of Return on Assets and Return on Equity for Banking and Insurance Companies on Vietnam Stock Exchange
}

\author{
Lucille V. Pointer, Phan Dinh Khoi
}

\begin{abstract}
A B S T R A C T
Objective: The objective of the article is to empirically examine the predictors of ROA and ROE for banks and insurance firms listed on the Vietnamese stock market.

Research Design \& Methods: The authors applied a quantitative approach. A basic OLS regression model is used to investigate key proposed predicators of ROA and ROE.

Findings: Internal variables are statistically significant predictors for both ROA and ROE in the study, including firm size, book value, return on equity, years in business, and earnings per share. The direction of causality is not consistent across the ratios. Capital structure was significant and negative for ROE. Banks earned lower return on their assets and higher return on their equity than insurance companies.

Implications \& Recommendations: Given the significance of internal variables such as firm size, return on equity, book value, years in business and earnings per share as predictors of ROA and ROE, management must focus on improving its internal organizational structure which affects these variables. Years in business is significant for both ROA and ROE which may reflect managers' tacit knowledge. Firms should cultivate stability within its managerial staff. To aid future growth, management must secure the proper combination of debt to equity funding.
\end{abstract}

Contribution \& Value Added: This article confirms past findings of internal predictors of ROA and ROE in banking. It is one of the first studies to examine predictors of ROA and ROE for firms in the insurance industry.

\begin{tabular}{ll}
\hline Article type: & research article \\
& return on assets; return on equity; banking; insurance; GLM; \\
& Vietnam
\end{tabular}

JEL codes: $\quad$ G21, G22

Received: 1 September $2019 \quad$ Revised: 12 November 2019 Accepted: 15 November 2019

\section{Suggested citation:}

Pointer, L., \& Khoi, P.D. (2019). Predictors of Return on Assets and Return on Equity for Banking and Insurance Companies on Vietnam Stock Exchange. Entrepreneurial Business and Economics Review, 7(4), 185-198. https://doi.org/10.15678/EBER.2019.070411 


\section{INTRODUCTION}

Return on Assets (ROA) and Return on Equity (ROE) are two useful analytical measures to assess the financial performance of companies. ROA refers to how efficient an organization is with the use of its assets. ROE shows how effective a firm is in utilizing its equity. Both can assess a firm's efficiency in generating earnings from investment, but they do not represent the exact same thing. Moreover, they may generate conflicting information about the financial health of a firm (McClure, 2018). Hannagan (2008) indicates that while ROA is still in use, ROE is a better tool due to its applicability across industries and firms of varying sizes within industries. Hence, McClure (2018) indicates that ROE is one of the most important of all the essential financial ratios. These ratios are also related to the capital structure of various organizations. Capital structure of a firm is a composite of the total mix of debt and equity held by the firm (Bokpin, 2009). Nor, Haron, Ibrahim, Ibrahim, and Alias (2011) indicate that even this mix is different in nature, as debt and equity complement each other, but the problem remains how to determine the best ratio of the two to efficiently operate a business. Kumar, Colombage, and Rao (2017) suggest that capital structure determinants serve as robust pillars that give competitive advantage to organizations. Accordingly, these factors jointly shape the financial mix of an organization and are dynamic in nature. These measures were often used in assessing the financial performance of firms in industries both in developed nations and emerging markets. Vietnam is considered one of the strongest emerging markets with many developing industries.

Vietnam transformed around 1986 into a market economy managed by the central government to create a favourable business environment for both domestic and foreign enterprises. The country became a model nation for implementing economic reforms. Its GDP rose to 245.2 billion USD in 2018 and averaged 6.3\% increase each year between 2005 and 2018 (CEIC data, 2019). Thus, Vietnam is one of the fastest growing economies in Southeast Asia (Nikkei Asian Review, 2019). As an emerging nation with a transitional economy, the country adopted many capitalist business traits since the early 1990s (Wang \& Lai, 2013). Many corporate financial decisions - especially capital structure - are based not only on the characteristics of the company but also on the volatility of macroeconomic factors. In other words, scholars theorize that business environment - like most market economies - plays a crucial role in many Vietnamese firms' performance.

Banking and insurance industries became vital components of the Vietnamese economy. The banking industry provides financial support for other promising industries, and is a requirement for sustainable growth in any economy (Almatqtari, Al-Homaidi, Tabash, \& Farhan, 2019; Menicucci \& Paolucci, 2016). The Vietnamese banking industry is dominated by state-owned commercial banks. The commercial banks account for close to $90 \%$ of deposits and, thus, are more influenced by political rather than market forces. Therefore, state-operated enterprises receive preferential treatment over private enterprises. State entities can often borrow monies with little collateral insurance or loans with subsidized interest rates. Bokpin (2009) shows that bank credit is a more significant factor than macroeconomic factors in predicting the capital structure in emerging economies. The growth of foreign banks was restricted because the Vietnamese government was focused on protecting its domestic industries prior to 1990s (McLaughlin \& Russell, 2002). Therefore, the financial performance and capital structure in the banking industry may be less 
affected by the normal macroeconomic variables as in other free market countries. The Vietnamese insurance industry developed into a significant market and is expected to continue to grow strongly in the near future. The insurance industry is not as regulated as the banking industry, so it is attractive to foreign investors.

Globalization has driven economic growth for many Vietnamese companies and the economy overall. This is reflected in the country's strong equity indices, which list many progressive firms. The Vietnamese Equity Index, (VnIndex) is a weighted index of all the companies listed on the Ho Chi Minh Stock Exchange.

The objective of the article is to empirically examine the predictors of Return on Assets (ROA) and Return on Equity (ROE) for banks and insurance firms listed on the Vietnamese stock market. The objective of this study is to use data from a representative sample of Vietnamese firms in the banking and insurance industries listed on the Ho Chi Minh Stock Exchange to investigate factors that influence the ROA and ROE. Our study adds to the literature on the factors that predict key financial ratios. This is one of the first studies to investigate the determinants of profitability of selected firms in both banking and insurance industries.

The article starts from the review of the literature on determinants of return on assets and return on equity of banking firms in different countries. The next section of the article covers the data and methodology; which is followed by an overview of the Vietnamese banking and insurance industries. The last section of this article discusses the empirical results; and Section 6 provides the conclusions, research limitations and recommendations.

\section{LITERATURE REVIEW}

When investigating the financial strength of firms, studies mainly focus on capital structure and specific financial ratios, such as return on assets (ROA) and return on equity (ROE) (see Nguyen, 2019; Chowdhury \& Rasid, 2017; Irfan \& Zaman, 2014; Menicucci \& Paolucci, 2016). ROA represents the net profits generated by banks' total assets while ROE represents the net profit on the capital invested by shareholders. Some researchers propose ROA as a better measure of profitability (Athanasoglou, Brissimi, \& Delis 2008; Staikouras \& Wood, 2004) while some indicate that ROE is a better measure (Mbekomize \& Mapharing, 2017; Goddard, Wilson, \& Molyneux 2004). Capital structure refers to the source of funds used by a firm to finance its business operations. Research on the variables related to capital structure and the financial ratios use very similar predictors.

Among the major predictors of ROA and ROE identified in the literature are GDP growth rate, interest rate, strength of the legal system, strength of creditor/shareholder protection/rights, stock market development, bond market development, country governance, size of firm, profitability, liquidity, competition, and business ownership (Batten \& Vo, 2019; Nguyen, Hoang, \& Biger 2008; Bokpin, 2009; Chowdhury \& Rasid, 2016; Menicucci \& Paolucci, 2016; Singh \& Sharma, 2016; Almaqtari, Homaidi, Tabash, \& Farhan,2019; Pacheco, 2019). These variables can be considered as either external or internal factors. External factors relate to the macroeconomic environment, which includes variables such as interest rates, GDP, the Consumer Price Index, money supply, and even the competitive structure of the market. Internal factors are the variables that reflect the internal capabilities and decisions of the organization and its managerial staff, such as years in business, firm size, capital structure, earnings, bank 
ownership, and book value. Macro environmental variables describe external market conditions, in which a firm must operate.

Using ten years of data from 69 commercial Indian banks, Almaqtari et al.(2019) finds that bank size, assets management ratios, and financial leverage ratio affect both ROA and ROE. In this study, the macroeconomic factors that have a significant effect on ROA and ROE include inflation rate, exchange rate, and interest rate. They also report that demonization had a significant impact on ROE but not ROA. When investigating the liquidity of banks in the Indian market, Singh and Sharma (2016) identify several macroeconomic factors that affect the banking industry, including GDP and inflation rate. Their study shows that more internal factors affect a bank's liquidity, including bank size, profitability, capital adequacy, and deposits. Menicucci and Paolucci (2016) find that bank deposit level has a significant positive affect on ROE and ROA in a study of European commercial banks.

Recent studies identify several key predictors of bank profitability in the Vietnamese banking market. Assessing the effects of market competition in the Vietnam banking market, Nguyen (2019) identifies three macroeconomic variables - competition, GDP, and inflation - as significant but negative predictors of ROA and ROE. Most of the internal variables are not key predictors of bank profitability, including bank size, liquidity, equity capital, nonperforming debt, and mergers and acquisitions. Since the findings show a nonlinear relationship between competition and profitability, Nguyen (2019) theorizes that the penetration of foreign banks undermines the marketing power of Vietnam banks. He calls for stronger protectionist policies. His findings do not show a consistent relationship between several key internal variables, including bank size, liquidity, equity capital, non-performing debt, and bank profitability. Nguyen et al., (2019) investigation of the financial soundness of Vietnamese commercial banks finds that overheads, deposits, ownership, and non-interest earning ratios negatively impact banks' financial soundness, whereas capital structure and bank reserves have a positive effect on banks' performance. Cuong and $\mathrm{Ha}$ (2018) examined factors that affect the financial management of 320 non-financial firms listed on the Vietnamese stock exchange. They identify seven financial factors - including ROA - as significant predictors of firms' success. Batten and Vo (2019) discover that both internal factors and macroeconomic variables affect bank profitability in the Vietnamese banking industry. Their findings identify bank size, capital adequacy, risk, expenses, and productivity as important predictors of ROE and ROA. Similarly, the direction of causality of predictors were not consistent across neither ROE nor ROA.

Research on the profitability of firms in the insurance market is limited. Using a panel data set from 41 insurance companies, Rahman, Jan, and Iqbal (2018) examine the profitability in this industry to reveal both endogenous and exogenous factors that influence profitability in Pakistan. Their findings show that business risk, leverage, and inflation significantly yet negatively affect profitability. Meanwhile, firm size and GDP rate affect profitability significantly and positively. Although their study does not specifically address ROA and ROE, it still provides insightful information about the market. Similar studies investigate variables related to firm efficiency measures - not specifically ROA and ROE -in the insurance industry in other countries (Hussels \& Ward, 2005; Luhnen, 2009; Afza \& Kauser, 2012; Akhtar, 2018).

There is a rich history of empirical literature on the nature and effects of factors related to financial ratios in developed economies, but the research on ROA and ROE in 
emerging economies - and insurance industry specifically - remains limited but developing (Kumar Colombage, \& Rao, 2017). Vietnam is considered one of the strongest emerging economies in Southeast Asia (Nikkei Asian Review, 2019), and its banking and insurance industries are vital to the country's continued economic development. Although several recent studies scrutinize the predictors of profitability in the banking industry (Batten \& Vo, 2019; Nguyen, 2019), their findings are mixed and limited. To date, there is very little empirical data on the predictors of ROA and ROE among firms in the insurance market. Given the importance of both these sectors to the Vietnamese economy, scholarship requires more research to examine these factors, as they affect key financial ratios, such as return on assets and return on equity of firms. Based on the literature review, we propose the following hypotheses.

Hypotheses for Return on Assets, specified equation (1):

HO: Independent variables have no effect on Vietnamese banking and insurance companies' Return on Assets $(\beta i=0)$.

H1: Independent variables have an effect on Vietnamese banking and insurance companies' Return on Assets $(\beta i \neq 0)$.

Hypotheses for Return on Equity, specified equation (2):

H0: Independent variables have no effect on Vietnamese banking and insurance companies' Return on Equity $(\beta \mathrm{i}=0)$.

H1: Independent variables have an effect on Vietnamese banking and insurance companies' Return on Equity $(\beta i \neq 0)$.

\section{MATERIAL AND METHODS}

\section{Research Methods and Econometric Model}

Several prior studies show that the ordinary least square linear regression model is acceptable for this form of analysis (Athanasoglou et al., 2008; Tiberiu, 2015; Menicucci \& Paolucci, 2016; Saona, 2016; Hoang, Nguyen, \& Hu, 2017; Almaqtari et al., 2019). The hypotheses were tested by estimating the following regression equations:

For the return on assets:

$$
\begin{aligned}
\text { roa }_{i, t}=\beta_{0}+\beta_{1} \text { roe }_{i, t}+\beta_{2} \text { cps }_{i, t}+\beta_{3} \text { Ita }_{i, t}+\beta_{4} \text { age }_{i, t}+\beta_{5} \text { bvs }_{i, t}+\beta_{6} \text { lep }_{i, t}+\beta_{7} \text { stp }_{i, t} \\
+\beta_{8} \text { cpi }_{t}+\beta_{9} \text { gdp }_{t}+\beta_{10} \text { per }_{t}+\beta_{11} \text { bms }_{t}+\beta_{12} \text { crs }_{t}+\beta_{13} \operatorname{dum}_{t}+\varepsilon_{i, t}
\end{aligned}
$$

And for return on equity:

$$
\begin{array}{r}
\text { roe }_{i, t}=\beta_{0}+\beta_{1} \text { roa }_{i, t}+\beta_{2} \text { cps }_{i, t}+\beta_{3} \text { Ita }_{i, t}+\beta_{4} \text { age }_{i, t}+\beta_{5} \text { bvs }_{i, t}+\beta_{6} \text { lep }_{i, t}+\beta_{7} \operatorname{stp}_{i, t} \\
+\beta_{8} \text { cpi }_{t}+\beta_{9} \text { gdp }_{t}+\beta_{10} \text { per }_{t}+\beta_{11} \text { bms }_{t}+\beta_{12} \text { crs }_{t}+\beta_{13} \text { dum }_{t}+\varepsilon_{i, t}
\end{array}
$$

where:

stp - stock price;

cps - capital structure - total debt to total asset ratio;

roa - return on asset;

roe - return on equity;

lta - natural log of total assets;

age - number of years in business;

bvs - book value per share; 
lep - natural log of earnings per share;

per - price to earnings ratio;

cpi - annual percentage change in consumer price index;

$g d p$ - annual growth of the GDP;

bms - annual change in Broad money supply $\mathrm{M}_{2}$;

crs - annual percentage change in credit extended to the economy by the central bank;

dum - dummy variable with the value of 1 if the company is a bank or 0 if the company is an insurance corporation;

$\beta_{\mathrm{j}}-j=0,1,2,3, \ldots, 13$ are coefficients to be estimated;

$\varepsilon_{\mathrm{i}, \mathrm{t}}-$ is the error term of the regression model.

\section{Data}

Annual data from 16 Vietnamese banks and ten insurance companies listed on the Ho Chi Minh Stock Exchange were extracted from consolidated financial reports of the listed banks and insurance companies on the Stock Exchange. The data on the \% changes in broad money supply $\mathrm{M}_{2}$ and in credit to the economy were collected from different IMF annual reports on Vietnam under Article IV of the IMF's Articles of Agreement. The IMF holds bilateral discussions with members, usually every year.

To scale down the different values in the data, the earnings per share and the total assets are the natural logarithms of actual values. Table 1 summarises the descriptive statistics for these variables of the model.

Table 1. Descriptive statistics of variables (annual data: 2008-2017)

\begin{tabular}{|c|r|r|r|r|r|r|r|r|}
\hline Variable & \multicolumn{1}{|c|}{ Mean } & \multicolumn{1}{c|}{ Median } & \multicolumn{1}{c|}{ Max. } & \multicolumn{1}{c|}{ Min. } & \multicolumn{1}{c|}{ Std. Dev. } & \multicolumn{1}{l|}{ Skew. } & \multicolumn{1}{c|}{ Kurt. } & Obs. \\
\hline$R O A$ & 0.80 & 0.03 & 8.10 & -5.99 & 1.65 & 2.11 & 9.46 & 251 \\
\hline$R O E$ & 3.87 & 0.13 & 25.20 & -56.33 & 7.15 & -1.49 & 21.75 & 256 \\
\hline$L T A$ & 6.41 & 6.25 & 9.08 & 3.38 & 1.50 & -0.06 & 1.92 & 257 \\
\hline$A G E$ & 21.76 & 20.00 & 61.00 & 1.00 & 12.99 & 1.33 & 4.56 & 246 \\
\hline$C P S$ & 30.16 & 11.34 & 558.06 & -55.91 & 54.26 & 6.77 & 58.24 & 257 \\
\hline$B V S$ & 2.05 & 1.23 & 4.50 & 0.30 & 1.41 & 0.74 & 1.64 & 253 \\
\hline$L E P$ & 2.75 & 3.01 & 3.92 & -3.66 & 0.96 & -3.44 & 19.05 & 252 \\
\hline$S T P$ & 17.41 & 13.80 & 64.50 & 2.10 & 11.70 & 1.49 & 5.45 & 153 \\
\hline$C P I$ & 8.38 & 6.60 & 22.97 & 0.63 & 6.76 & 1.05 & 2.93 & 257 \\
\hline$G D P$ & 6.03 & 5.98 & 6.81 & 5.03 & 0.60 & -0.21 & 1.79 & 257 \\
\hline$P E R$ & 21.65 & 8.60 & 350.00 & 1.33 & 50.53 & 4.78 & 26.54 & 151 \\
\hline$B M S$ & 19.84 & 18.40 & 33.30 & 12.10 & 6.06 & 1.12 & 3.23 & 257 \\
\hline$C R S$ & 20.05 & 17.40 & 39.60 & 8.70 & 9.05 & 0.94 & 2.82 & 257 \\
\hline
\end{tabular}

Source: cophieu68.vn and IMF Reports and calculations by the authors.

\section{Overview of Vietnamese Banking and Insurance Industries}

Over the past three decades, the Vietnamese government undertook a series of reforms to modernize the banking sector as part of the country's move towards a more open and market-oriented economy. Many of these reforms were motivated by Vietnam's growing participation in international agreements and its ongoing efforts to adopt international standards, such as the Basel capital framework (Nguyen, Stewart, \& Matousek 2018). The 
main objectives of the reforms include a restructuring of the banking system, gradual opening to foreign direct investments, partial privatization of state-owned banking institutions, and measures to strengthen the capitalization of Vietnamese banks. A part of the reform included transforming the Vietnamese banking industry from a mono system to a two tier banking system with the State Bank of Vietnam (SBV) as the first tier and four lower specialized state-owned banks serving as the second tier in 1986-2009 (Nguyen et al., 2018). In 1990, banking rules were changed and the banking system opened to nonstate-owned and foreign banks. The non-state-owned commercial bank sector consists of joint stock commercial banks, branches of foreign banks, joint venture commercial banks, and foreign commercial banks. State-owned commercial banks still maintain a competitive edge over other banks. Stewart, Matousek, and Nguyen (2016) indicate that, "three of the five state owned commercial banks held $45 \%$ of customer deposits, $41 \%$ of total assets and $51 \%$ of customer loans." Although state-owned banks issue the majority of loans, it is not a favourable financial situation, because state-owned banks hold a disproportionate number of non-performing loans compared to non-state-owned commercial banks (Nguyen et al., 2018). Many of the Vietnamese commercial banks focus on granting more shortterm, loans which also affects their profitability (Nguyen et al., 2008), and most of these loans are granted to state-owned enterprises (Nguyen \& Ramachandran, 2006). Nguyen et al. (2018) comprehensively investigate the Vietnamese banking industry to find that the five state-owned commercial banks still dominate the whole banking system, but nonstate-owned commercial bank are more efficient. One of the conclusions of their report is that - given the market structure - the Vietnamese banking system still operates as a monopoly. According to Van-Thep and Day-Yang (2019), the Vietnamese banking industry faces many difficulties, including credit risk, liquidity risk, lack of competiveness, and low governance capacity which results in poor performance.

The Vietnam insurance industry is very dynamic and expanding with growth expected in all sectors of the industry (Trang, 2018). The industry is fragmented but the two largest segments are life insurance and non-life. The life insurance segment is the largest, accounting for $45.6 \%$ of the insurance industry's gross written premium in 2013. Insurance companies and brokers are governed by a specific Insurance Business law established in 2009, administered by the Ministry of Finance. Insurance companies may be entirely foreign own entities or joint venture organizations. They may be licensed for up to 50 years, but they are prohibited from providing insurance to state-owned enterprises (McLaughlin \& Russell, 2002).

In 2016, the Association of Vietnam Insurers (AVI) listed a total 63 companies in the insurance industry, including 31 non-life, 17 life insurance, two reinsurance companies, one foreign life insurance branch, and 12 insurance brokers. The number of insurers in the market is projected to increase by over $50 \%$ within two to three years. The Vietnamese insurance market total revenue was estimated to be worth over 100,000 billion VND in 2016. The insurance industry revenue represented 2\% of the country's GDP in 2016 and is forecasted to more than double its share of GDP in five years, according to the Association of Vietnam Insurers. Tiwari (2018) indicates that, "Vietnam has one of the world's most dynamic and rapidly expanding insurance industries."

Unlike the banking industry, the Vietnamese insurance industry is not dominated by state-owned firms. Market growth and development is attributed to foreign companies, 
which dominate the market either by direct investment or joint ventures. Foreign companies bring experience and training to a young underdeveloped market, which is ripe for growth. The Vietnamese market is very attractive, because the per capita income increases while the population ages (World Bank, 2019). Older Vietnamese are becoming more sensitive to the need for insurance, especially life insurance (Trang, 2018). The percentage of people in the middle class grew from $21 \%$ to $39 \%$ in 2012-2016. Although the majority of the population is considered young, the percentage of 45 years and older grew from $26 \%$ to $31 \%$ in $2014-2016$, which indicates an aging population.

Vietnamese insurance agencies are predicted to expand distribution channels through banks, joint ventures, and foreign direct investments, as more international firms come into the market (Trang, 2018). Several large USA-based insurance companies or brokers entered the Vietnamese markets with offices in both Hanoi and Ho Chi Minh City. The largest segment of the market is life insurance, which experienced the fastest growth between $2012-2017$. In this period, the life segment grew by $28 \%$ compared to only $12 \%$ for the non-life insurance segment. The non-life insurance segment provides coverage for homes, cars, and businesses. Large foreign insurance companies dominate the life insurance segment with $78 \%$ share of the market. The segment is predicted to grow by nearly $30 \%$ (Li, 2018). American insurance firms, such as Prudential, AIG, and Chubb, compete in this segment. Domestic insurance firms are more dominant in the non-life insurance segment with Bao Viet as the largest domestically-owned company. Bao Viet competes in both segments of the insurance market (Trang, 2018).

\section{RESULTS AND DISCUSSION}

Theoretically, a panel data set with 16 banks and ten insurance companies over a tenyear sample period should have $26 \times 10=260$ observations. As is always the case with emerging economies, missing data is a formidable challenge in empirical studies. Our investigation faced a similar challenge. The missing data reduced the data set to only 145 complete data points out of possible 260 observations and rendered the observations to an unbalanced panel data set.

In this analysis, the robustness of models is tested with two estimation methods and the above data set. A few available methods may be used to estimate equation (1) using unbalanced panel data. Given the relatively few observations with 145 complete data points and a model with 13 independent variables, this analysis uses the Panel Least Squares and Generalized Linear Model (Newton-Raphson/Marquardt steps) to estimate the model.

Interestingly, the results from the two estimation methods are identical in terms of statistical significance of the estimated coefficients. Table 2 summarizes the estimation results from the Panel Least Squares method for both equation (1) and (2). We provide the estimation results from Generalized Linear Model (Newton-Raphson / Marquardt steps).

The analysis of estimation results for the return on assets in equation (1) reveals that the model fits the data set very well, as evidenced by the F-statistic $=38.2954$, which is significant at the $1 \%$ level. The adjusted $\bar{R}^{2}=0.77$ is also very good for panel data. For the sample companies, factors which were statistically positive and significant at the $1 \%$ 
level for ROA included, the estimated coefficient for the return on equity, roe $_{i, t}$, firm size, measured with the natural logarithm of the total assets of the company, Ita $a_{i, t}$, in Vietnamese "dong," and the book value per share. Since the natural logarithmic function cannot operate on a negative number, we take its natural log of absolute value and then assign a negative sign to the result so as to transform the negative number into a natural algorithmic value. These findings suggest that return on equity, firm size, years in business, book value, and earnings per share affect return on assets of companies. The estimated coefficients of the years that the companies were in business and the natural log of earnings per share are negative and significant at the $1 \%$ level, which is counterintuitive.

Table 2. The estimation of results for Equation (1) and Equation (2) for 2008-2017 annual data

\begin{tabular}{|c|c|c|c|c|c|c|}
\hline \multirow{2}{*}{ Variable } & \multicolumn{3}{|c|}{ Return on Asset (ROA) } & \multicolumn{3}{|c|}{ Return on Equity (ROE) } \\
\hline & Coeff. & t-stat. & Prob. & Coeff. & t-stat. & Prob. \\
\hline Return on Assets & - & - & - & 1.991 & 9.0245 & 0.000 \\
\hline Return on Equity & 0.193 & 9.025 & 0.000 & - & - & - \\
\hline Firm size & 0.286 & 3.264 & 0.001 & -2.461 & -12.403 & 0.000 \\
\hline Years in business & -0.044 & -5.686 & 0.000 & 0.166 & 7.0197 & 0.000 \\
\hline Capital Structure & 0.001 & 0.542 & 0.589 & -0.012 & -3.226 & 0.002 \\
\hline Book value per share & 0.558 & 7.194 & 0.000 & -1.018 & -3.621 & 0.000 \\
\hline Earnings per share & -0.513 & -5.682 & 0.000 & 1.022 & 3.281 & 0.001 \\
\hline Stock price & 0.006 & 0.719 & 0.474 & 0.026 & 0.946 & 0.346 \\
\hline Percentage change in $\mathrm{CPI}$ & 0.013 & 0.950 & 0.344 & 0.041 & 0.937 & 0.350 \\
\hline GDP growth & -0.091 & -0.657 & 0.512 & -0.066 & -0.147 & 0.884 \\
\hline Price to earnings ratio & -0.001 & -0.841 & 0.402 & -0.001 & -0.412 & 0.681 \\
\hline Percentage Change in $\mathrm{M} 2$ & 0.008 & 0.364 & 0.717 & -0.024 & -0.352 & 0.725 \\
\hline Credit to the economy & 0.006 & 0.340 & 0.735 & 0.015 & 0.296 & 0.768 \\
\hline Dummy & -1.146 & -6.430 & 0.000 & 4.467 & 8.446 & 0.000 \\
\hline Constant & 0.552 & 0.494 & 0.622 & 10.995 & 3.173 & 0.002 \\
\hline Diagnostic Statistics & \multicolumn{3}{|c|}{$\begin{array}{l}\bar{R}^{2}=0.7710 \\
F-\text { statistic }=38.2954^{*} \\
\text { Log likelihood }=-167.3973 \\
\text { Akaike info criterion }=2.5020\end{array}$} & \multicolumn{3}{|c|}{$\begin{array}{l}\bar{R}^{2}=0.8031 \\
F-\text { statistic }=46.18209 * \\
\text { Log likelihood }=-336.745 \\
\text { Akaike info criterion }=4.8379\end{array}$} \\
\hline
\end{tabular}

Source: Data from Annual reports of banks and insurance companies listed in Ho Chi Minh Stock Exchange. * indicates the significance level at the $1 \%$.

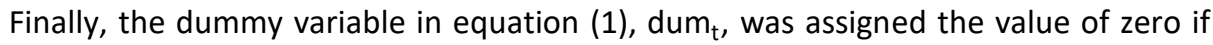
the data was from an insurance company and one if the information was from a bank. This value assignment to dum $\mathrm{m}_{\mathrm{t}}$ and its estimated coefficient is negative and significant at the $1 \%$ level, which suggests that banks and insurance companies listed in the Ho Chi Minh Stock Exchange have different levels of return on assets. The findings suggest that ROE, the years firms were in business, the book value of firms, and earnings per share influence the insurance industry stronger than the banking industry. More specifically, the estimated coefficient of the dummy variable is negative and significant, which suggests that banks earned lower return on their assets than insurance institutions.

A closer look at the estimation results for the return on equity, equation (2), reveals that the model fits the data set very well, as evidenced by the F-statistic $=46.182$, which is significant at the $1 \%$ level. The adjusted $\bar{R}^{2}=0.80$ is also very good for panel data. Regarding factors 
that influence the return on equity of sample companies, the estimated coefficients for the return on assets, roa $_{i, t}$, years in business, and the natural log of earnings per share size are positive and statistically significant at the $1 \%$ level. The estimated coefficients of firm size, measured by the natural logarithm of the company's total assets, book value per share, and capital structure are negative and significant at the $1 \%$ level. These findings indicate that all these elements negatively affect the return on equity of the companies.

Finally, the dummy variable in equation (2), dum $\mathrm{t}_{\mathrm{t}}$, was also assigned the value of zero if the data is from an insurance company and one if the information is from a bank. The estimated coefficient for this dum $\mathrm{m}_{\mathrm{t}}$ is positive and statistically significant at the $1 \%$ level. Again, this suggests that banks and insurance companies listed in the Ho Chi Minh Stock Exchange have different equity structures. More specifically, this finding suggests that $\mathrm{Vi}$ etnamese banks earned higher return on their equity than insurance institutions.

The results corroborate the mixed findings regarding the effects of macroeconomic and internal variables reported in many studies on ROA and ROE. In our study, none of the macroeconomic variables were predictors of either ROA or ROE. However, previous studies do find both types of variables as predictors of these financial measures; namely, Batten and Vo (2019) and Nguyen (2019), who specifically study the Vietnam banking market and report both macroeconomic and firm-specific factors to predict bank profitability. Nguyen (2019) reports a non-linear relationship between bank profits and competitive factors in the Vietnamese banking market. Almaqtari et al. (2019) and Singh and Sharma (2016) report that internal variables predict both financial measures in a study of the Indian banking market. Almaqtari et al. (2019) find no external variables to predict ROA but several to predict ROE. Singh and Sharma (2016) show that GDP and inflation are significant predictors of bank liquidity. In this study, the majority of the factors that influence bank liquidity are internal variables, such as bank size, profitability, capital adequacy, deposits, and years in business.

While specific research on factors that predict the profitability of insurance firms is unavailable, related research by Trang, Thai, Tuan, and Tho (2017) seems to corroborate the importance of internal factors on the financial behaviour of insurance firms. Trang et al. (2017) show that internal variables ROS (earnings before tax on sales) and ETA (measure of owners' equity to assets) are positively related to stock trading efforts of insurance firms.

\section{CONCLUSIONS}

Empirical results show that the major predictors of key financial ratios - the Return on Assets and the Return on Equity - are the internal variables affected by firms' financial management decisions. Significant predictors of Return on Assets are return on equity, firm size, years in business, book value, and earnings per share. For Return on Equity, the key predictors are return on assets, firm size, years in business, capital structure, book value, and earnings per share. A closer review of our findings reveals that - while these key predictors are significant - the causality is not consistent across both ROA and ROE, similar to the findings of Batten and Vo (2019) and Almaqtari et al. (2019). Capital structure is normally an important factor for many firms, but in our study it appeared only as a significant but negative predictor of return on equity and not a predictor for return on assets. Furthermore, the results show that banks earn lower return on assets and higher return on equity than insurance companies. The findings about banks may be indicative of what 
Nguyen et al. (2018) reported about Vietnamese banks which operate in a monopoly market structure. The insurance market is regulated but does not appear to be as controlled by the government as the banking industry, which may mean that insurance companies are less restricted in pursuing business opportunities. As mentioned above, state-owned banks account for a sizeable amount of bank loans, and many of these loans are underperforming loans to state-owned enterprises.

Since internal variables are significant predictors of these key variables, management must focus efforts on improving its internal structure. Since years in business is significant for both ROA and ROE, it may be a reflection of the tacit knowledge and decision-making ability of managers, especially in the insurance industry. Tacit knowledge is gained through experience, which is difficult to transfer but could be a major contributor to effective managerial and financial decisions. Therefore, firms should cultivate stability among their management staff. Book value is a gauge that investors use to evaluate a stock's value, which is significant and positive for ROA, though significant and negative for ROE. Thus, management must work to secure the proper combination of debt to equity funding. Both ratios - along with capital structure - are important and can improve a firm's ability to attract new funding for future growth in both industries.

\section{Research Limitations and Suggestions for Further Studies}

This study used data from only 26 firms, mostly banks, over a ten-year sample period. To increase the reliability of our generalizations, the sample size should be increased according to the projected changes in the Vietnamese economy. As mentioned above, the Vietnam economy is expected to continue its rapid growth. Therefore, the number of firms trading on the stock market should increase, because it is an attractive mechanism to raise capital. Additionally, the mix of government owned to private own banks is changing because more banks are being converted to private ownership. This could affect the competitive market structure which Nguyen (2019) shows can affect performance of the banks in the industry. Since major macroeconomic variables were significant predictors of both ROA and ROE in other studies but not his study, future research is needed to see if this is still the case because of the changing market structures. The insurance market in Vietnam is expected to continue its growth and will become an even more attractive investment opportunity for local and international firms. As the insurance market expands and matures, industry specific research will be needed to explore factors that affect profitability and other market issues.

\section{REFERENCES}

Afza, T., \& Kausar, M. (2012). Financial Reforms and efficiency in the insurance companies of Pakistan. African Journal of Business Management, 6(30), 8957-8963.

Akhtar, M.H. (2018). Performance analysis of Takaful and conventional insurance companies in Saudi Arabia. Benchingmarking: An International Journal, 25(2), 677-695. http://doi.org/10.1108/BIJ-01-2017-0018

Almaqtari, F.A., Al-Homaidi, E.A., Tabash, M.I., \& Farhan, N.H. (2019). The determinants of profitability of Indian commercial banks: A panel data approach. International Journal of Finance \& Economics, 24(1), 168-185. http://doi.org/ 10.1002/ijfe.1655 
Athanasoglou, P.P., Brissimi, S.N., \& Delis, M.D. (2008). Bank-specific and industry-specific and macroeconomic determinants of bank profitability. Journal of Inter-national Financial Markets, Institutions, and Money. 18(2), 121-136. http://doi.org/10.1016/j.intfin.2006.07.001

Batten, J., \& Vo, X.V. (2019). Determinants of bank profitability - evidence from Vietnam. Emerging Markets Finance \& Trade, 55, 1417-1428. http://doi.org/10.1080/1540496X.2018.1524326

Bokpin, G.A. (2009). Macroeconomic development and capital structure decisions of firms: Evidence from emerging market economies. Studies in Economics and Finance, 26(2), 129-142.

CEIC (2019). Vietnam real GDP growth. Retrieved from https://www.ceicdata.com/en/indicator/vietnam/real-gdp-growth on August 29, 2019.

Chowdhury, M.A.F., \& Rasid, M.E.S.M. (2016). Determinants of performance of Islamic banks in GCC countries: Dynamic GMM approach. In Advances in Islamic Finance, Marketing, and Management: An Asian Perspective, 49-80. Emerald Group Publishing Limited.

Cunog, N.T., \& Ha, N.T.T. (2018). Influence of financial ratios on earnings management: Evidence from Vietnam Stock Exchange Market. Journal of Insurance and Financial Management, 4(1), 57-77.

Goddard, J., Wilson, J.O.S., \& Molyneux, P. (2004). The profitability of European Banks: A cross-sectional and dynamic panel analysis. Manchester School, 72(3). http://doi.org/10.1111/j.14679957.2004.00397

Hannagan, T. (2008). ROE vs ROA. Retrieved from http://www.experian.com/blogs/insights/2008/12/roe-vs-roa/ on August 29, 2019.

Hoang, L.T., Nguyen, C.C, \& Hu, B. (2017). Ownership structure and firm performance Improvement: Does it Matter in the Vietnamese Stock market. Economic Papers, 16(4), 416-428. http://doi.org/10.1111/1759-3441.12185

Hussels, S., \& Ward, D. (2005). The Impact of deregulation on the German and UK life insurance markets: an analysis of efficiency and productivity between 1991-2002 (Working Paper). Bradford University School of Management, Bradford.

Irfan, M., \& Zaman, K. (2014). The performance and efficiency of Islamic banking in South Asian Countries. Economia: Seria Management, Faculty of Management, Academy of Economic Studies, Romania, 17(2), 223-237.

Kumar, S., Colombage, S., \& Rao, P. (2017). Research on capital structure determinants: a review and future directions. International Journal of Managerial Finance. 13(2), 106-132. http://doi.org/10.1108/IJMF-09-2014-0135

$\mathrm{Li}, \mathrm{A}$. (2018). Life Insurance Developments in Vietnam. Retrieved from https://www.prnewswire.co.uk/news-releases/vietnam-life-insurance-industry-and-reinsurance-market-2018-forecasts-in-new-research-reports-290730871.html on August 3, 2019.

Luhnen, M. (2009). Determinants of efficiency and productivity in German property liability insurance evidence for 1995-2006. The Geneva Papers on Risk and Insurance Issues and Practice, 34(3), 483-505. http://doi.org/10.1057/gpp.2009.10

Mbekomize, C.J., \& Mapharing, M. (2017). Analysis of determinants of profitability of commercial banks in Botswana. International Journal of Academic Research in Accounting, Finance and Management Sciences, 7(2), 131-144.

McClure, B. (2018). How ROA and ROE give a clear picture of corporate health. Retrieved from www.investodpedia.com on July 18, 2019.

McLaughlin, M., \& Russell, N. (2002). Vietnam. International Financial Law Review Supplement. Banking Yearbook, London, 77-82. 
Menicucci E., \& Paolucci, G. (2016). The determinants of bank profitability: empirical evidence from European banking sector. Journal of Financial Reporting and Accounting, 14(1), 86-115. http://doi.org/10.1108/JFRA-05-2015-0060

Nguyen, T.N., Stewart, C., \& Matousek, R. (2018). Market structure in the Vietnamese banking system: a non-structural approach. Journal of Financial Regulation and Compliance, 26(1), 103119. http://doi.org/10.1108/JFRC-03-2016-0024

Nguyen, H.P. (2019). Profitability of Vietnamese Banks Under Competitive Pressure. Emerging Markets Finance and Trade, 55(9), 2004-2021. http://doi.org/10.1080/1540496X.2018.1511977

Nguyen, N.V., Hoang, Q.X., \& Biger, N. (2008). The determinants of capital structure: Evidence from Vietnam. International Review of Financial Analysis, 8(1).

Nguyen, T.D.K., \& Ramachandran, N. (2006). Capital structure in small and medium sized enterprises: The case of Vietnam. ASEAN Economic Bulletin, 23(2), 192-211.

Nikkei Asian Review. (2019). Vietnam economy grows nearly $7 \%$ on trade war tailwinds. Retrieved from https://asia.nikkei.com/Economy/Vietnam-economy-grows-nearly-7-on-trade-war-tailwinds on July 25, 2019.

Nor, F.M., Haron, R., Ibrahim, K., Ibrahim, I., \& Alias, N. (2011). Determinants of target capital structure evidence on South East Asia countries. Journal of Business and Policy Research, 6(3), 39-61.

Pacheco, L. (2019). Performance vs. family ownership and management: The case of the Portuguese Wine Firms. Entrepreneurial Business and Economics Review, 7(3), 7-24. http//doi.org/10.15678/EBER.2019.070301.

Rahman, S.U., Jan, M.F. \& Iqbal, K. (2018). Determinants of profitability in Life and Non-life insurance sector of Pakistan: An endogenous and exogenous evaluation. Journal of Independent Studies \& Research: Management \& Social Sciences \& Economics, 16(2), 97-105.

Saona, P. (2016). Intra- and extra- bank determinants of Latin American banks' profitability. International Review of Economics and Finance, 45, 197-214. http//doi.org/10.1016/j.iref.2016.06.004

Singh, A., \& Sharma, A.K. (2016). An empirical analysis of macroeconomic and bank-specific factors affecting liquidity of Indian Banks. Future Business Journal, 2(1), 40-53.

Staikouras, C.K., \& Wood, G.E. (2004). The determinants of European bank profitability. International journal of Economics and Business Research, 3(6), 57-68.

Stewart, C., Matousek, R., \& Nguyen, T.N. (2016). Efficiency in the Vietnamese Banking system: A DEA double bootstrap approach. Research in International Business and Finance, 36, 96-111.

Tiberiu, C. (2015). Banks' profitability and financial soundness indicators: A macro-level investigation in emerging countries. Procedia Economics and Finance, 23, 203- 209.

Tiwari, R. (2018). Vietnam Life Insurance industry and reinsurance market forecast. Retrieved from https://www.prnewswire.co.uk/news-releases/vietnam-life-insurance-industry-and-reinsurance-market-2018-forecasts-in-new-research-reports-290730871.html on August 29, 2019.

Trang, M., Thai, P., Tuan, N.M., Tho, N.H. (2017). The role of financial ratio in the variance of stock trading volume in emerging stock market. Journal of Asia-Pacific Business, 18(3), 180-191. http://doi.org//10.1080/10599231.2017.1346408.

Trang, N.T.H. (2018). Vietnam Insurance Market Report. Retrieved from https://www. slideshare.net/StoxPlusCorporation/vietnam-insurance-market-report-2018 on August 30, 2019.

Van-Thep, N., \& Day-Yang, L. (2019). Determinants of financial soundness of commercial banks: Evidence from Vietnam. Journal of Applied Finance and Banking, 9(3), 35-63.

Wang, K., \& Lai, H. (2013). Which global stock indices trigger stronger contagion risk in the Vietnamese stock market: Evidence using a bivariate analysis. Panoeconomicus, 60(4), 473-497. 
World Bank (2019). Vietnam Overview. Retrieved from https://www.worldbank.org/en/country/vietnam/overview on August 15, 2019.

\section{Authors}

The contribution share of authors is equal and amounted to $50 \%$ each of them.

\section{Lucille Pointer}

PhD in Marketing (Texas A\&M University), MBA (University of Wisconsin), Bachelor of Science (Southern University). She teaches both undergraduate and graduate marketing courses. She has published in many peer reviewed journals. Her research interests include sales promotion, buyer behaviour, supply chain management, and macroeconomic variables affecting entrepreneurs and businesses.

Correspondence to: Prof. Lucille Pointer, Marilyn Davies College of Business, University of Houston-Downtown, Houston, TX, 77002, USA, e-mail: pointerl@uhd.edu

ORCID (1) http://orcid.org/0000-0002-2896-3189

\section{Phan Dinh Khoi}

$\mathrm{PhD}$ in Finance from Lincoln University, New Zealand. He is Assistant Professor of Finance and Chair of the Department of Finance and Banking at the College of Economics, University of Can Tho, Can Tho, Vietnam. He has published papers in international peer-reviewed journals, including the Journal of Asian Economics and the Journal of the Asia-Pacific Economy. His research focuses on development finance and economics, corporate finance, and banking.

Correspondence to: Prof. Phan Dinh Khoi, Department of Finance and Banking at the College of Economics, Can Tho University, Vietnam, e-mail: pdkhoi@ctu.edu.vn

ORCID (1) http://orcid.org/0000-0001-9097-1043

\section{Acknowledgements and Financial Disclosure}

The authors gratefully thank the reviewers for their very helpful comments and recommendations on the article.

\section{Copyright and License}

This article is published under the terms of the Creative Commons

Attribution - NoDerivs (CC BY-ND 4.0) License

http://creativecommons.org/licenses/by-nd/4.0/

\section{Published by the Centre for Strategic and International Entrepreneurship - Krakow, Poland}

